\title{
Peranan United Nations Joint Program On HIVIAIDS (UNAIDS) Terhadap Penurunan Tingkat Penderita HIVIAIDS Di Zimbabwe
}

\author{
Nurul Anisa Asri \\ Muhammad Nasir Badu \\ Pusparida Syahdan \\ Department of International Relations, Hasanuddin University \\ Makassar, Indonesia
}

\begin{abstract}
This study aims to examine the role of UNAIDS in efforts to reduce the rate of HIV / AIDS sufferers in Zimbabwe. The research method used is qualitative with secondary data techniques in the form of books, journals, documents, and various valid sources. All data were analyzed qualitatively. The results of this study indicate that UNAIDS as an international organization has become an aid and channel of foreign aid to Zimbabwe in collaboration with the Zimbabwean government to reduce the level of sufferers in the country. The existence of UNAIDS in Zimbabwe has affected the reduction of HIV / AIDS sufferers. However, this collaborative effort has constraints on Zimbabwe's unfavorable economic and human resource conditions. Apart from that, the cultural factor of society which is quite difficult to accept changes in something is also an obstacle.
\end{abstract}

Keywords: Zimbabwe; UNAIDS; HIV / AIDS

\section{ABSTRAK}

Penelitian ini bertujuan untuk mengetahui peran UNAIDS dalam upaya penurunan tingkat penderita HIVIAIDS di Zimbabwe. Metode penelitian yang digunakan adalah kualitatif dengan teknik pengumpulan data-data sekunder berupa buku, jurnal, dokumen, dan berbagai sumber valid. Seluruh data dianalisa secara kualitatif. Hasil penelitian ini menunjukkan bahwa UNAIDS sebagai sebuah organisasi internasional menjadi bantuan dan penyalur bantuan luar negeri kepada Zimbabwe bekerja sama dengan pemerintah Zimbabwe untuk mengurangi tingkat penderita di negara tersebut. Keberadaan UNAIDS di Zimbabwe telah mempengaruhi penurunan tingkat penderita HIVIAIDS. Namun, upaya kerjasama ini memiliki hambatan yakni kondisi perekonomian dan sumber daya manusia di Zimbabwe yang kurang baik. Selain itu faktor kebudayaan masyarakat yang cukup sulit menerima perubahan akan suatu hal juga menjadi salah satu hambatan.

Kata Kunci : Zimbabwe; UNAIDS; HIVIAIDS

\section{PENDAHULUAN}

HIV (Human Immune Deficiency Virus) merupakan virus yang menyerang system kekebalan tubuh manusia sehingga tubuh tidak dapat melindungi diri dari serangan berbagai macam penyakit. Virus inilah yang menyebabkan AIDS. AIDS (Acquired Immune Deficiency Syndrome) merupakan kumpulan dari gejala dan infeksi atau biasa disebut sindrom yang diakibatkan oleh kerusakan sistem kekebalan tubuh manusia karena virus HIV. Namun, tidak semua orang yang terjangkit HIV menderita AIDS. Angka harapan hidup bagi orang yang terkena HIV sekitar 10-15 tahun atau bisa lebih namun ini sangat jarang terjadi. Penyebaran virus ini bisa melalui hubungan sex yang tidak aman, jarum suntik, ASI, transfuse darah dan tranplantasi organ atau jaringan tubuh (UNICEF, 2006).

Sekitar 34 juta orang di dunia terjangkit HIV dan 1,7 juta orang meninggal karena AIDS pada tahun 2011 (Global Summary of the Aids Epidemic 2011). Sebagian besar penderita HIV adalah remaja dan anak-anak. Lebih dari $90 \%$ orang dengan HIV AIDS (ODHA) terdapat di 
negara-negara berkembang utamanya negara-negara di kawasan Afrika dan Asia. Negaranegara di kawasan Afrika utamanya negara-negara sub-sahara sejak dulu selalu menjadi perhatian terkait penyebaran virus HIV.69\% dari jumlah penderita HIV di dunia berada di wilayah tersebut. Negara-negara di Afrika dengan penderita HIV tertinggi diantaranya Swaziland, Botswana, Leshoto, Afrika Selatan dan Zimbabwe. Negara-negara tersebut termasuk dalam 5 (lima) negara dengan jumlah HIV penderita tertinggi (UNAIDS, 2012).

Dari 5 (lima) negara dengan penderita HIV terbanyak sebagaimana yang disebutkan di atas, yang menarik adalah negara Zimbabwe di mana jumlah penderita HIV di negara ini menurun dari tahun-tahun sebelumnya. Kasus pertama yang dilaporkan di Zimbabwe pada tahun 1985.Pada saat itu terdapat sekitar $10 \%$ dari angka populasi terinfeksi HIV. Angka tersebut meningkat drastis hingga tahun 1997 yakni mencapai 26,5\% dari angka populasi. Pada saat itu, perhatian terhadap masalah HIV masih sangat minim utamanya dari pemerintah. Hal ini diperparah dengan buruknya pelayanan dan fasilitas kesehatan yang ada di Zimbabwe. Saat ini, $14 \%$ dari jumlah penduduk Zimbabwe terkontaminasi HIV Jumlah ini sudah menurun dari tahun-tahun sebelumnya (avert.org)

Dalam penanganan kasus HIV di Zimbabwe yang sudah diketahui sejak tahun 1985 pemerintah sangat lambat dalam menangani permasalahan tersebut.

Selain itu, diskusi ataupun pembicaraan terkait penanganan penyebaran HIV sangat jarang dilakukan. Meskipun demikian, NACP (National AIDS Coordination Programme) dan beberapa program jangka pendek dan menengah diadakan oleh pemerintah. Namun ini tidak bertahan lama. Selanjutnya pada tahun 1999 pemerintah mendirikan National AIDS Council (NAC) (avert.org). Disini terlihat bagaimana Zimbabwe di awal perumusan kebijakan penanganan AIDS belum begitu maksimal.

Sebagai sebuah negara berkembang, Zimbabwe juga menjalin kerja sama dengan UNAIDS (Joint United Nations Programme on HIVIAIDS) yang merupakan organisasi internasional yang bertugas untuk menanggulangi atau menekan penyebaran virus HIVIAIDS di seluruh dunia. Organisasi ini beroperasi dengan mempromosikan kerjasama dengan agen PBB lainnya, pemerintah, media massa dan aktor lainnya. UNAIDS membantu pencegahan epidemi yang lebih besar terutama di negara-negara berkembang. UNAIDS membantu pemerintah Zimbabwe berupa bantuan teknis dan dana. UNAIDS mensponsori berbagai tindakan advokasi di beberapa tempat di Zimbabwe untuk meningkatkan informasi dan layanan kesehatan di negara tersebut (United Nations General Assembly Report On HIVAIDS, Zimbabwe Country Report, 2008).

UNAIDS adalah badan PBB yang berbasis di Jenewa, sekretariat UNAIDS bekerja pada lebih 75 Negara dan didirikan pada tahun 1994 oleh Resolusi Dewan Ekonomi dan Sosial yang diluncurkan pada bulan Januari 1996. Melalui serangkaian tujuan, Resolusi dan Deklarasi yang diadopsi oleh negara-negara anggota PBB, dunia memiliki seperangkat komitmen, tindakan dan tujuan untuk menghentikan dan membalikkan penyebaran HIV dan skala ke arah akses universal untuk pencegahan HIV, pengobatan, perawatan dan dukungan layanan (UNAIDS, 2015)

Pada tahun 2001, Majelis Umum PBB mempertimbangkan isu-isu HIVIAIDS dan pada UN General Assembly Special Session on HIVIAIDS (UNGASS) Declaration of Commitment yang ditandatangani oleh perwakilan dari 189 negara, menyatakan bahwa negara-negara penandatanganan harus membuat mekanisme monitoring dan evaluasi yang memadai untuk mengukur dan menilai kemajuan pelaksanaan komitmen, serta membuat instrument monitoring dan evaluasi serta menyediakan data epidemiologik yang memadai. Pada tahun 2006, kembali diadakan Political Declaration on HIVIAIDS dimana Zimbabwe merupakan salah satu negara yang menandatangani deklarasi tersebut. Hal ini juga menegaskan kembali Deklarasi dan Komitmen pada tahun 2001 mengenai Millenium Development Goals, khususnya tujuan untuk menghentikan dan mulai membalikkan penyebaran HIVIAIDS pada tahun 2015 (Declaration of Comitment on HIVIAIDS, 2006).

Sebagai sebuah organisasi internasional tentunya tidak memiliki kewenangan penuh untuk langsung mengambil langkah teknis dalam penanganan HIVIAIDS di Zimbabwe. Tentunya, 
ada komitmen dari pemerintah sendiri dalam menangani hal tersebut dengan programprogram yang dijalankannya. Selain itu, ada beberapa LSM yang giat dalam memperjuangkan masalah penyebaran HIVIAIDS. Namun, dalam hal ini tentunya UNAIDS sebagai sebuah organisasi internasional mempunyai bantuan-bantuan yang diberikan kepada negara-negara berkembang dengan jumlah penderita HIVIAIDS yang terbilang tinggi termasuk Zimbabwe.

Jumlah penderita HIVIAIDS di Zimbabwe yang dapat menurun dari $26,5 \%$ menjadi $14 \%$ dari angka populasi merupakan sebuah titik cerah bagi Zimbabwe dalam penanganan HIVIAIDS. Tidak dapat dipungkiri bahwa keberhasilan pemerintah Zimbabwe ini tidak lepas dari peranan berbagai pihak termasuk UNAIDS sebagai organisasi internasional di bawah PBB yang memang khusus menangani hal tersebut juga berbagai bantuan baik pendanaan, fasilitas maupun bantuan teknis lainnya di tengah banyaknya LSM maupun organisasi pemerintah sendiri yang menangani masalah HIVIAIDS.

Beberapa penelitian menunjukkan bahwa angka penderita HIV IAIDS di negara dimana UNAIDS terlibat dalam penanganannya justru menunjukkan peningkatan jumlah penderita seperti yang terjadi di Indonesia. Namun, di Zimbabwe terjadi penurunan jumlah penderita HIVIAIDS dari $26, \%$ menjadi $14 \%$ dari jumlah populasi. Dengan pembahasan mengenai Peranan United Nations Joint Program on HIVIAIDS (NNAIDS) dalam mengurangi penyebaran virus HIVIAIDS di Zimbabwe. Menimbulkan ketertarikan penulis untuk meneliti bagaimana Peranan UNAIDS dalam mengurangi penyebaran virus HIVIAIDS di Zimbabwe, yang akan diberi judul "Peranan United Nations Joint Program on HIVIAIDS (UNAIDS) terhadap penurunan tingkat penderita HIVIAIDS di Zimbabwe".

\section{KERANGKA ANALISIS}

Hubungan kerjasama antara pemerintah Zimbabwe merupakan salah satu dari sekian banyak fenomena hubungan internasional dalam hal ini state actor dan non state actor. Ketika berbicara mengenai pola hubungan kerjasama yakni negara Zimbabwe dan Organisasi international UNAIDS. Organisasi Internasional merupakan pola kerjasama yang melintasi batas- batas negara, dengan didasari struktur organisasi yang jelas dan lengkap serta diharapkan atau diproyeksikan untuk berlangsung serta melaksanakan fungsinya secara berkesinambungan dan melembaga guna mengusahakan tercapainya tujuan-tujuan yang diperlukan serta disepakati bersama, baik antara pemerintah maupun antara sesama kelompok non pemerintah pada negara yang berbeda.

Menurut Clive Archer dalam bukunya yang berjudul International Organization mendefinisikan organisasi internasional adalah sebuah struktur formal yang berkelanjutan yang dibentuk atas dasar kesepakatan antar anggota (negara dan non negara) yang berdaulat dengan bertujuan untuk mengejar kepentingan bersama para anggota (Archerm, 1983). Pembentukan organisasi internasional dibentuk atas dasar saling membutuhkan karena setiap negara tidak mungkin dapat memperjuangkan kepentingan negaranya sendiri. Sehingga dengan kerjasama yang dilakukan atas dasar kesepakatan sebelumnya, tujuantujuan yang merupakan kepentingan dari negara tersebut dapat dicapai.

Organisasi internasional memiliki bentuknya sendiri, hal ini di jelaskan dalam dua kategori organisasi internasional oleh Ley Roy Bennet berikut ini:

1. Organisasi antar pemerintah (inter-governmental organizations/lGO), anggota berasal dari perwakilan negara seperti : PBB, WTO, NATO.

2. Organisasi non pemerintah (Non-governmental onganizations/NGO), anggotanya berasal dari kelompok non negara seperti kelompok bidang keilmuan, budaya, ekonomi, HAM. Contohnya Palang Merah, greenpeace (Roy Bennet)

Dengan demikian, jelaslah bahwa suatu organisasi internasional dibentuk untuk mencapai suatu tujuan yang telah disepakati bersama oleh para anggotanya. Misalnya, dengan keanggotaan 189 Negara bertujuan untuk mengurangi penyebaran virus HIV di dunia. Untuk itu, UNAIDS kemudian berintegrasi dengan negara-negara anggotanya termasuk Zimbabwe dalam memerangi penyebaran virus HIV dan menangani para penderita HIV AIDS di dunia. 
Keberadaan UNAIDS sebagai sebuah organisasi internasional memiliki latar belakang dan tujuan. Hal inilah yang kemudian mendorong organisasional ini untuk memiliki programprogram kerja yang tidak terlepas dari fungsinya. Program kerja guna mencapai tujuan yang telah ditentukan sebelumnya, dituangkan dalam berbagai bentuk cara kerja, salah satunya melalui kerjasama.

Kerjasama yang dijalin oleh UNAIDS bukan hanya melibatkan pihak yang terbatas namun dapat melibatkan berbagai pihak. Dalam hal ini UNAIDS sebagai aktor dalam hubungan internasional yaitu organisasi internasional menjalin interaksi dengan berbagai aktor lainnya. Interaksi ini dapat berupa kerjasama dalam bidang yang telah disepakati. Dalam hal ini bidang kesehatan, dimana isu ini merupakan isu yang kontemporer dalam studi ilmu hubungan internasional dan menarik perhatian banyak pihak serta melibatkan banyak aktor.

UNAIDS memiliki kerjasama dalam bidang kesehatan dengan aktor Zimbabwe. Sebagai sebuah negara Zimbabwe memiliki masalah yang juga dihadapi oleh negara lain di belahan dunia lain, yaitu penyebaran virus HIV yang berakibat pada terjangkitnya masyarakat Zimbabwe. Mengingat masalah ini dihadapi buka hanya oleh Zimbabwe, maka dapat dikatakan bahwa masalah kesehatan oleh virus HIV ini adalah masalah internasional yang dihadapi olehmasyarakat internasional. Salah satu aktor internasional yang kemudian mengambil peran untuk membantu negara-negara di dunia adalah UNAIDS melalui berbagai program dan kerjasama yang melibatkan berbagai pihak (USAID, 2015) termasuk pemerintah suatu negara.

Dengan keanggotaan 189 Negara bertujuan untuk mengurangi penyebaran virus HIV di dunia. Untuk itu, UNAIDS kemudian berintegrasi dengan negara- negara anggotanya termasuk Zimbabwe dalam memerangi penyebaran virus HIV dan menangani para penderita HIV AIDS di dunia. Dalam perjalanannya, penanganan kasus HIV tentunya membutuhkan banyak bantuan baik itu secara teknis maupun berupa dana dari luar negeri. Bantuan luar negeri merupakan bentuk dari kebijakan luar negeri. Secara umum, bantuan luar negeri dapat diartikan sebagai transfer sumberdaya dari suatu pemerintah ke pemerintah yang lain baik berupa uang, jasa, maupun dana.

Dalam perjalanannya, penanganan kasus HIV tentunya membutuhkan banyak bantuan baik itu secara teknis maupun berupa dana dari luar negeri. Bantuan luar negeri merupakan bentuk dari kebijakan luar negeri. Secara umum, bantuan luar negeri dapat diartikan sebagai transfer sumberdaya dari suatu pemerintah ke pemerintah yang lain baik berupa uang, jasa, maupun dana (USAID, 2015).

Menurut KJ. Holsti, Bantuan luar negeri sebagai transfer uang, teknologi, ataupun nasihatnasihat teknis dari pendonor kepada penerima. Ada 4 (empat) tipe utama bantuan luar negeri : Technical assistancel Bantuan Teknis; Grants/ Hibah dan program impor komoditi; pinjaman pembangunan; dan bantuan kemanusiaan yang sifatnya darurat (USAID, 2015). Menurut Alan Rix, Pelaksanaan Pemberian bantuan Luar negeri tidak lepas dari motivasi para pemberi bantuan. Di antaranya dapat berupa motif kemanusiaan, motif politik, motif keamanan nasional dan motif yang berkaitan dengan kepentingan nasional negara pendonor (USAID, 2015).

Selanjutnya, agenda internasional saat ini tidak hanya mengenai isu-isu keamanan militer saja tapi juga menyangkut sosial, ekonomi, HAM, kesejahteraan, lingkungan hidup hingga isu kesehatan. HIVIAIDS tidak hanya merusak terhadap kesehatan, melainkan membawa efek tidak langsung terhadap berbagai bidang kehidupan, terutama pada bidang ekonomi dan bidang sosial. Sebagai badan Internasional, UNAIDS berintegrasi dengan negaranegara yang terkontaminasi virus HIVIAIDS. UNAIDS membantu negara-negara untuk bantuan penyusunan dan pelaksanaan program-program kerjasama yang dianggap mampu memberikan hasil yang lebih efektif dalam penanggulangan HIVIAIDS. Memimpin, memperkuat dan mendukung respon yang meluas terhadap HIV dan AIDS yang termasuk mencegah transmisi HIV, menyediakan fasilitas dan dukungan untuk orang yang sudah terlanjur hidup dengan virus HIV dan mengurangi dampak epidemik virus HIVIAIDS adalah 
misi dari UNAIDS yang diterapkan oleh seluruh negara, terutama negara berkembang seperti Zimbabwe.

Penyebaran Virus HIV di berbagai negara di dunia menjadi perhatian berbagai kalangan mulai dari individu, kelompok masyarakat, pemerintah, maupun organisasi Internasional. Hubungan Internasional yang tidak lagi didominasi oleh negara, melainkan untuk mencapai tujuan bersama beberapa organisasi Internasional kemudian dibentuk termasuk UNAIDS sebagai IGO dengan tujuan melawan penyebaran virus HIV di dunia.

\section{METODE PENELITIAN}

Metode yang digunakan dalam penelitian ini adalah metode deskriptif analitik. Dalam teknik pengumpulan data, penulis menelaah sejumlah literatur yang berkaitan dengan masalah yang diteliti berupa buku, jurnal, dokumen, artikel dalam berbagai media, baik internet maupun surat kabar harian. Adapun bahan- bahan tersebut diperoleh dari Perpustakaan Pusat Universitas Hasanuddin di Makassar.

Jenis data yang penulis gunakan adalah data sekunder. Data sekunder merupakan data yang diperoleh melalui studi literatur. Seperti buku, jurnal, artikel, dan situs internet yang berkaitan dengan rumusan masalah yang akan diteliti. Selanjutnya data diolah dengan teknik analisis kualitatif.

\section{HASIL DAN PEMBAHASAN}

\section{Program Kerja UNAIDS di Zimbabwe}

Sehubungan dengan tantangan yang ada, pada tahun 1994, PBB mendirikan UNAIDS yang mulai diluncurkan pada Januari 1996 dengan melibatkan 10 organisasi untuk bergabung menjadi pendukung program-program gabungan PBB terhadap HIVIAIDS.UNAIDS berpedoman pada Programme Coordinating Board (PCB) yang terdiri dari perwakilan 22 pemerintah dari seluruh dunia, perwakilan dari para kosponsor dan 5 perwakilan dari NGO, termasuk asosiasi korban penderita HIVIAIDS.UNAIDS merupakan badan PBB pertama yang mengikutsertakan NGO dalam badan pemerintahannya.

UNAIDS merupakan IGO yang bernaung di bawah PBB yang menangani permasalahan HIVIAIDS di seluruh dunia, dengan logo pita merah (red ribbon) didirikan berdasarkan Resolution of The United Nations Economic and Social Council (ECOSOC) pada bulan Desember tahun 1994 (UNAIDS, 2016). UNAIDS sendiri didirikan berdasarkan kreasi Dr. Peter Piot (Direktur Eksekutif UNAIDS) dan di bawah Sekretaris Jenderal PBB. Dengan melakukan kerjasama dengan UNAIDS, para kosponsor dapat lebih memperluas jangkauannya melalui kerjasama strategi dengan badan PBB lainnya, negara, badan hukum, media, organisasi-organisasi keamanan, kelompok masyarakat yang terinfeksi HIVIAIDS dan NGO baik dalam lingkup regional maupun negara.

UNAIDS dalam menjalankan tugas-tugasnya mendapatkan bantuan dari agen-agen PBB yang memiliki kualifikasi di bidang masing-masing, sehingga akan memudahkan kerja UNAIDS di seluruh dunia, yang biasa disebut kosponsor UNAIDS. Keberadaan kosponsor bagi UNAIDS memberi keuntungan dimana dapat menambah sinergi dan efisiensi kerja UNAIDS, dan Kosponsor juga bagi UNAIDS berkontribusi untuk membantu dalam mengimplementasikan kegiatan- kegiatan penanggulangan HIVIAIDS. Kosponsor juga membantu dalam menyediakan bantuan yang dibutuhkan oleh UNAIDS, seperti bantuan teknis, bantuan rancangan program, memberikan masukan-masukan. Terdapat beberapa kosponsor yang juga membantu pendanaan UNAIDS. UNAIDS bersama-sama dengan kosponsor yang ada bertujuan untuk membangun koordinasi yang lebih efektif dalam upaya penanggulangan HIVIAIDS, meningkatkan efisiensi kerja UNAIDS, dan juga membangun kemitraan yang harmonis dalam pelaksanaan kegiatan-kegiatan yang berhubungan dengan penanggulangan epidemi HIVIAIDS.

UNAIDS bersama dengan para kosponsor berusaha untuk meningkatkan dan memperluas respon dari negara-negara untuk penanggulangan HIVIAIDS. Dengan adanya UNAIDS dan kosponsor, maka koordinasi upaya penanggulangan HIVIAIDS dapat dilakukan dengan lebih 
mudah. Karena dapat dihindari terjadinya tumpang tindih pengalokasian bantuan terhadap program nasional dimana isu HIVIAIDS ini juga akan berintegrasi dengan program-program yang relevan.

Fokus utama dari UNAIDS adalah untuk memperkuat kapabilitas nasional dalam menghadapi epidemik HIVIAIDS ini. UNAIDS mempunyai peranan yang saling memperkuat dalam aktivitas UNAIDS di tingkat negara, antar negara maupun di tingkat regional, yaitu:

- Policy Development and Research, bertujuan untuk mengidentifikasikan, membangun dan menjadi sumber utama di dalam penelitian pada skala internasional

- Technical Support, menyelidiki penyebab dan menyediakan bantuan teknis untuk memperkuat kapabilitas nasional dalam memperkuat respon terhadap HIVIAIDS.

- Advocacy, sebagai pelopor yang memulai respon yang komprehensif dari berbagai sector dan didukung dengan bantuan teknis dan strategis yang baik serta akan disediakan sumber yang memadai.

- Coordination, bertujuan mengkoordinasikan dan merasionalisasikan kegunaankegunaan dari para sponsor dan badan PBB lain dalam mendukung usaha mengurangi epidemik.

Mekanisme kerja UNAIDS, sebagai organisasi internasional yang mengkhususkan diri untuk menanggulangi permasalahan HIVIAIDS di seluruh dunia mempunyai mitra kerjasama yang berasal dari berbagai kalangan. Untuk mengkoordinir dan mengakomodasi semua program atau kegiatan dan perencanaan yang dibuat oleh UNAIDS, maka UNAIDS mempunyai mekanisme kerja yang terbagi ke dalam struktur organisasi, dimana disetiap bagiannya mengemban tugas dan tanggung jawab yang saling berkaitan. Bagian-bagian dalam struktur organisasi UNAIDS yakni UNAIDS memiliki sebuah sekretariat yang berpusat di Jenewa, Swiss. Sekretariat UNAIDS berperan sebagai koordinator untuk segala aktifitas UNAIDS. Sekretariat UNAIDS beroperasi sebagai katalisator dan koordinator aksi terhadap HIVIAIDS dibanding sebuah badan atau organisasi pelaksana, fungsinya adalah:

- Facilitation, staff UNAIDS mengkoordinasikan dan mengefektifkan usaha-usaha yang dilakukan oleh para kosponsor dan badan-badan PBB lainnya dalam melawan HIVIAIDS.

- Best Practice, sekretariat UNAIDS membantu pembuat kebijakan-kebijakan dan strategi yang berkaitan dengan epidemik ini, mengacu pada pengalaman yang telah berhasil dilakukan oleh negara-negara lain.

- Advocacy, dalam tingkat internasional, staff UNAIDS bertugas untuk mempromosikan kegunaan "Best Practice". Selain itu mereka juga berupaya menyatukan negaranegara donor, sector swasta, NGO dan juga masyarakat yang hidup dengan HIVIAIDS untuk melawan HIVIAIDS.

- Trafficking the epidemic, pusat yang mengumpulkan, menganalisa dan menyebarluaskan informasi mengenai epidemik ini dan apa saja yang telah dilakukan untuk menanggulanginya.

Program coordinating board (PCB), UNAIDS dibimbing oleh PCB, sebagai badan pemerintahan UNAIDS. Badan ini beranggotakan perwakilan dari 22 negara diseluruh dunia, perwakilan dari 10 kosponsor dan 5 perwakilan NGO, dimana di dalamnya terdapat asosiasi pengidap HIVIAIDS. PCB atau Dewan Pengkoordinasi Program mempunyai beberapa fungsi utama, seperti mengeluarkan kebijakan dan menentukan program apa yang akan dilakukan guna mengatasi epidemik HIVIAIDS. Untuk menentukan langkah apa yang akan diambil, PCB harus melakukan introspeksi dan menganalisis faktor-faktor penentu seperti data epidemik dan perubahan jumlah penderita HIVIAIDS, maka PCB akan dapat mengambil langkah-langkah yang dinilai tepat untuk mengatasi epidemik HIVIAIDS.

Selain bertugas untuk merancang program yang akan dilaksanakan, PCB juga harus mempelajari kembali dan menentukan persetujuan atas perencanaan keuangan. Perencanaan keuangan sehubungan dengan dana yang dibutuhkan untuk membiayai program-program UNAIDS yang akan dilakukan. Perencanaan keuangan ini dipersiapkan 
oleh Direktur Eksekutif dan Komite Organisasi Pendukung (CCO). PCB juga berkewajiban untuk mengevaluasi usaha-usaha yang sudah dilakukan oleh para organisasi pendukung untuk kosponsor, kemudian PCB membuat rekomendasi untuk para kosponsor mengenai langkah-langkah apa yang harus diambil selanjutnya yang berhubungan dengan aktifitas mereka dalam program penanggulangan HIVIAIDS. Dan tugas terakhir PCB, yaitu PCB juga harus mempelajari kembali laporan periode untuk mengevaluasi kemajuan program dan dari hasil yang ada dapat dilihat sejauh mana efektifitas dari program-program yang sudah dilaksanakan.

Committee of cosponsoring organization (CCO), Komite organisasi pendukung bertindak sebagai forum bagi para organisasi pendukung atau kosponsor untuk bertemu dan menyampaikan masukan terkait dengan program- program yang dilaksanakan oleh UNAIDS. CCO mengadakan pertemuan secara rutin sebagai komite penyeimbang dari PCB. CCO juga bertugas mempertimbangkan permasalahan-permasalahan di UNAIDS, serta memberikan masukan-masukan bagi para kosponsor untuk membuat kebijakan dan langkahlangkah strategis bagi UNAIDS.

CCO mempunyai beberapa fungsi utama, seperti mempelajari kembali rencana kerja yang telah disusun serta laporan pendanaan dan laporan keuangan program-program yang akan dijalankan untuk setiap periode keuangan. Hal ini dilakukan CCO agar rencana kerja yang telah disusun benar-benar tepat untuk dilaksanakan. Setelah mempelajari semua rencana kerja dan laporan keuangan yang ada, maka CCO berkewajiban untuk mempertanggung jawabkannya kepada PCB. Selain itu, CCO juga membuat rekomendasi untuk aspek-aspek tertentu agar disetujui oleh PCB. Setelah semua langkah tersebut berhasil diselesaikan, maka CCO bertugas untuk mempelajari kembali aktifitas yang dilakukan oleh masingmasing kosponsor, apakah sesuai dan mendukung seluruh kegiatan UNAIDS.

Theme Group adalah sebuah bagian dari mekanisme kerja UNAIDS yang anggotanya terdiri dari para kepala dari organisasi pendukung atau kosponsor UNAIDS yang ada di suatu negara tertentu dan juga dari badan-badan PBB lain yang masih berkaitan. Theme Group bertujuan untuk mendukung segala usaha menanggulangi HIVIAIDS secara komprehensif di sebuah negara tertentu. Di beberapa negara, Theme Group juga dapat terdiri dari pemerintah dimana Theme Group berada. Tidak hanya pemerintah, namun juga orang pemerintah yang berada di negara-negara itu juga tergabung dalam Theme Group.

Theme Group diketuai oleh salah seorang ketua perwakilan dari organisasi pendukung atau kosponsor UNAIDS dan setiap 2 tahun sekali akan berputar secara bergiliran dengan ketua perwakilan kosponsor yang lain. Program kerja dari Theme Group ini akan berbeda-beda, tergantung dari situasi masing-masing negara. Namun pada prinsipnya program kerja untuk Theme Group ini akan meliputi : mengumpulkan informasi-informasi terkait data yang dibutuhkan untuk penanggulangan HIVIAIDS dalam suatu negara tertentu, menganalisa program- program yang akan dilakukan dan mengkoordinasikan aksi bersama untuk penanganan HIVIAIDS.

Country Programme Adviser (CPA),Dibeberapa negara tertentu, kelompok pengusul tema atau Theme Group dibantu oleh CPA. Biasanya CPA ditempatkan di negara yang sedang berkembang untuk membantu negara tersebut dalam mengimplementasikan programprogram UNAIDS. Tugas utama yang diemban oleh CPA adalah untuk membantu Theme Group dalam mendapatkan respon nasional suatu negara yang baik dalam program penanggulangan HIVIAIDS. Juga untuk memastikan kebijakan UNAIDS diterapkan dengan baik di negara yang telah ditunjuk (UNAIDS, 2016).

CPA bertugas untuk mendorong terciptanya pendekatan yang baru dan inovatif dalam menghadapi epidemik HIVIAIDS. CPA menyebarluaskan informasi terbaru mengenai data yang terkait dengan HIVIAIDS dan penanganannya di negara tertentu. CPA mempunyai kewajiban untuk menciptakan komitmen yang kuat diantara pemerintah yang berwenang, para pemberi dana, media massa, masyarakat sipil dan sector swasta dalam memperkuat serta memperluas respon nasional terhadap upaya penanggulangan epidemik HIVIAIDS. Selain itu, CPA juga harus dapat menyediakan dukungan teknis yang diperlukan oleh negara 
dalam pengimplementasian UNAIDS.

Technical Working Group berperan sebagai badan pelaksana operasional bagi Theme Group. Technical Working Group terdiri dari perwakilan mitra kegiatan UNAIDS yang berada dalam negara tertentu. Technical Working Group berfungsi untuk membantu pengimplementasian program-program yang disusun oleh Theme Group. Biasanya, Technical Working Group menangani daerah spesifik, dimana Theme Group membutuhkan bantuan untuk membantu negara dalam mengimplementasikan program-program UNAIDS. Technical Working Group ini juga harus mengamati perkembangan dan pelaksanaan dari aktifitas program yang telah ditetapkan dan melaporkannya kembali pada Theme Group.

Dalam melaksanakan kegiatan operasionalnya, UNAIDS membagi 2 daerah kegiatannya, yaitu Country Support, Bertujuan memperkuat dan mendukung kapabilitas nasional untuk mengkoordinasi, merencanakan, mengimplementasikan, memonitor dan mengevaluasi respon terhadap HIVIAIDS. Fokus utama UNAIDS pada level negara adalah meningkatkan kapabilitas nasional dalam mengambil tindakan untuk HIVIAIDS dan memastikan adanya tanggapan atau kepedulian terhadap epidemik ini untuk jangka waktu yang panjang. Country Support yang bertujuan memperkuat dan mendukung kapabilitas nasional untuk koordinasi, rencana, implementasi, monitor dan evaluasi respon terhadap HIVIAIDS

Tugas UNAIDS pada Country Support, yakni membentuk mekanisme dari aksi bersama dalam mendukung dan memonitor semua usaha nasional dalam menanggulangi HIVIAIDS. Menyediakan dukungan untuk Theme Group dalam menjalankan tugasnya terutama dalam penyebarluasan informasi. Menyediakan dan memfasilitasi bantuan teknis untuk memperkuat kapasitas nasional. Menyediakan dan memfasilitasi bantuan teknis untuk national HIVIAIDS Programme, kosponsor, NGO dan para penderita HIVIAIDS. Memperkuat kapasitas kepemimpinan nasional untuk mengkoordinasikan, memimpin dan mengevaluasi respon terhadap HIVIAIDS. Mempertahankan komitmen politis, keterlibatan multisektoral dan membangun kondisi yang kondusif untuk respon HIVIAIDS, terutama dalam kaitannya dengan HAM.

Selanjutnya adalah International Best Practice, bertugas mengidentifikasikan, membuat dan mempertahankan kebijakan-kebijakan, strategis yang diperlukan dalam menghadapi epidemik HIVIAIDS dengan mengacu pada apa yang telah berhasil dilakukan oleh negara lain. Kontribusi UNAIDS untuk negara-negara adalah menganalisa segala bentuk aksi yang telah dilakukan berkaitan dengan pencegahan HIVIAIDS dan mengambil pelajaran dari sini. Aktifitas yang terbukti berhasil secara efektif dan efisien, dianjurkan untuk dapat ditiru oleh negara-negara lain, termasuk segala pengalaman dari para kosponsor, LSM dan para penderita HIVIAIDS, yang kemudian akan dijadikan bahan masukan bagi negara.

UNAIDS memperluas respon ini dengan fokuskan pada kebijakan- kebijakan, strategi yang dapat mengurangi resiko terhadap HIVIAIDS, seperti promosi kondom, pendidikan seks yang sehat. Serta pada kebijakan yang bertujuan untuk mengurangi kerentanan terhadap HIVIAIDS dan efek-efek yang ditimbulkannya.

Tugas UNAIDS pada International Best Practice yaitu membantu pertukaran informasi, jaringan kerja, komunikasi antar para partner dalam mengumpulkan, menganalisa dan mempromosikan Best Practice. Memberikan bantuan teknis termasuk informasi dan training untuk memastikan bahwa Best Practice dapat berjalan dengan baik di tingkat negara. Menyebarluaskan Best Practice secara umum dan memberikan bantuan yang diperlukan di tiap negara. Menciptakan mekanisme bagi para partner UNAIDS dalam pembentukan kebijakan, riset dan evaluasi untuk Best Practice. Memonitor dan memperkirakan kecenderungan penyebaran virus HIVIAIDS di seluruh dunia dan juga terus memantau respon terhadap epidemik ini pada tingkat negara, antar negara dan juga tingkat global. Terus memperkuat kapabilitas dari UNAIDS sebagai sumber utama dalam pembuatan berbagai kebijakan, strategi dan petunjuk teknis untuk HIVIAIDS serta mempersatukan potensi yang ada di dalam maupun di luar sistem PBB.

\section{Situasi HIVIAIDS di Zimbabwe}


Zimbabwe merupakan negara Afrika yang berbatasan dengan Namibia di barat melalui sebuah jalur sempit. Terkait perekonomian, Zimbabwe terus mengalami kemorosotan selama beberapa waktu ini. Inflasi negeri ini terus meningkat hingga 2,2 juta persen (Antaranews) yang menjadi inflasi tertinggi di dunia. ${ }^{36}$ Akibat inflasi yang tinggi tersebut, bank sentral Zimbabwe sudah mengeluarkan 4 versi mata uang sampai sekarang. Terakhir kali bank sentral Zimbabwe mengeluarkan pecahan \$100,000,000,000,000 (100 triliun dolar) yang menjadi uang dengan nominal terbesar di dunia yang kemudian digantikan dengan dolar versi ke-4 di mana setiap \$100,000,000,000,000 (100 triliun dolar) uang lama digantikan menjadi $\$ 1$ uang baru. Dengan ekonomi yang terus memburuk sekarang bank sentral Zimbabwe memutuskan untuk membolehkan rakyatnya menggunakan mata uang dolar Amerika sebagai mata uang mereka untuk menstabilkan kembali ekonomi Zimbabwe.

Sistem kesehatan di Zimbabwe merupakan salah satu yang terburuk di dunia di mana tingkat harapan hidup untuk pria hanya sampai umur 44 tahun dan 43 tahun untuk wanita (BBC) hasil ini menunjukkan penurunan dibandingkan pada tahun 1990. Penurunan ini disebabkan karena kasus HIVIAIDS. Tingkat kematian bayi juga meningkat dari 5,9\% pada akhir tahun 1990 an menjadi $12,3 \%$ pada tahun 2004 (BBC), sementara itu pada waktu yang bersamaan terjadi tingkat kelahiran bayi yang meningkat secara drastis.

Sistem fasilitas kesehatan juga tidak berbeda jauh dengan kondisi kesehatan masyarakat. Pada akhir November 2008, tiga dari empat rumah sakit besar di Zimbabwe ditutup (BBC).Selain itu, para dokter dan ahli medik juga melakukan migrasi besar-besaran seiring dengan memburuknya keadaan politik dan ekonomi (BBC).

Pada Agustus 2008, sebagian besar daerah Zimbabwe mengalami epidemikolera. Keadaan ini semakin parah dengan 10.000 orang terinfeksi kolera di hampir seluruh provinsi di Zimbabwe. Epidemi ini juga tersebar hingga ke negara tetangga seperti Botswana, Mozambik, Afrika Selatan dan Zambia (BBC).

Terkait dengan masalah kesehatan d Zimbabwe, pada bab ini penulis akan menjelaskan terlebih dahulu mengenai HIV dan menjelaskan kondisi HIV di Zimbabwe. HIV adalah virus yang menyerang sistem kekebalan tubuh manusia dan kemudian menimbulkan AIDS. Virus ini menyerang organ-organ vital sistem kekebalan tubuh manusia, seperti sel T4 CD4+ makrofag, dan sel dendritik. HIV merusak sel T4 CD4+ secara langsung dan tidak langsung, sel T4 CD4+ dibutuhkan agar sistem kekebalan tubuh dapat berfungsi baik.

Sejak dilaporkan adanya kasus AIDS yang pertama oleh Gottlieb dkk. di Los Angeles pada tanggal 5 Juni 1981, pada bulan Januari 1983 Luc Montagnier dkk, menemukan virus penyebab penyakit AIDS ini dan disebut dengan LAV (Lymphadenopathy Virus). Hasil penelitian Gallo, Maret 1984 di Amerika menyatakan penyebab penyakit ini adalah Human $T$ Lymphotropic Virus Type III, disingkat dengan HTLV III dan tahun 1984 berdasarkan hasil penemuannya, J.Levy menamakan AIDS Related Virus (ARV) sebagai penyebab penyakit ini. Pada bulan Mei 1986 Komisi Taksonomi Internasional menetapkan nama virus penyebab AIDS adalah Human Immunodeficiency Virus, disingkat dengan HIV.

HIV adalah virus RNA yang termasuk dalam famili Retroviridae subfamily Lentivirinae. Retrovirus mempunyai kemampuan menggunakan RNA- nya dan DNA pejamu untuk membentuk virus DNA dan dikenali selama periode inkubasi yang panjang. Satu kali terinfeksi oleh retrovirus, maka infeksi ini akan bersifat permanen, seumur hidup.

AIDS merupakan singkatan dari Aquired Immune Deficiency Syndrome. Syndrome berarti kumpulan gejala-gejala dan tanda-tanda penyakit. Deficiencyberarti kekurangan, Immune berarti kekebalan, dan Aquired berarti diperoleh atau didapat, dalam hal ini "diperoleh" mempunyai pengertian bahwa AIDS bukan penyakit keturunan. Seseorang menderita AIDS bukan karena ia keturunan dari penderita AIDS, tetapi karena ia terjangkit atau terinfeksi virus penyebab AIDS. Oleh karena itu, AIDS dapat diartikan sebagai kumpulan tanda dan gejala penyakit akibat hilangnya atau menurunnya sistem kekebalan tubuh seseorang.

AIDS merupakan suatu sindrom yang amat serius, dan ditandai oleh adanya kerusakan sistem kekebalan tubuh penderitanya. Dapat diartikan sebagai kumpulan gejala atau penyakit yang disebabkan oleh menurunnya kekebalan tubuh akibat infeksi oleh virus HIV. 
AIDS merupakan tahap akhir dari infeksi HIV.

Pada pertengahan tahun 1980an, HIV dan AIDS hampir tidak ada di Afrika Selatan. Kini daerah ini adalah salah satu daerah yang paling parah angka infeksinya. Tidak ada tandatanda penurunan angka infeksi di wilayah ini. Ada sebelas negara di wilayah ini: Angola, Namibia, Zambia, Zimbabwe, Botswana, Malawi, Mozambik, Afrika Selatan, Lesotho dan Swaziland, serta kepulauan Madagaskar. Dalam laporan yang dibuat pada bulan Desember 2005, UNAIDS melaporkan bahwa ada penurunan angka infeksi di Zimbabwe. Akan tetapi banyak pemerhati independen menyatakan bahwa angka yang diberikan oleh Robert Mugabe tidak dapat dipercaya, terutama karena angka infeksi di negara- negara lain di Afrika bagian selatan terus meningkat (terkecuali sedikit penurunan di Botswana). Hampir $30 \%$ dari seluruh populasi orang dengan HIV di seluruh dunia tinggal di wilayah ini, padahal di wilayah ini hanya bermukim $2 \%$ dari seluruh penduduk dunia. Hampir semua negara di wilayah ini memiliki tingkat prevalensi setidaknya 10\%.Pengecualian dari nilai ini adalah Angola dengan nilai prevalensi kurang dari $5 \%$.Hal ini tidak disebabkan oleh berhasilnya program penanggulangan, tetapi karena perang saudara yang berkelanjutan.

Kebanyakan infeksi HIV di wilayah ini adalah jenis HIV-1, jenis yang paling banyak ditemukan di dunia, yang paling sering ditemukan di wilayah- wilayah dunia dengan populasi penduduk dengan HIV. Pengecualian adalah Afrika bagian barat, di mana infeksi HIV-2 lebih sering ditemukan. Di wilayah Afrika bagian selatan, kasus pertama HIV dilaporkan dari Zimbabwe pada tahun 1985 (UNAIDS, 2016).

Menurut data dari UNAIDS tahun 2008, di kawasan Sub-Sahara Afrika terdapat 22,4 penderita HIVIAIDS, dengan PR pada orang dewasa sebesar 5,2\%. Di Asia Selatan dan Asia Tenggara terdapat 3,8 juta ODHA dengan PR pada orang dewasa sebesar 0,3\%. Di Asia Timur terdapat 850.000 penderita HIVIAIDS dengan jumlah kematian 59.000 kasus.

Menurut data UNAIDS (2009), dalam survei yang dilakukan di negara bagian Sub-Sahara Afrika antara tahun 2001 dan 2005, prevalensi HIV lebih tinggi di daerah perkotaan daripada di daerah pedesaan, dengan rasio prevalensi HIV di kota : pedesaan yaitu 1,7:1. Misalnya di Ethiopia, orang yang tinggal di areal perkotaan 8 kali lebih mudah terinfeksi HIV dari pada orang-orang yang tinggal di pedesaan. Program-program yang dilakukan oleh Zimbabwe untuk menghadapi masalah ini yakni dengan menerapkan program Zimbabwe National HIV and Aids Strategic Program, ZNASP adalah kebijakan nasional pemerintah Zimbabwe, tepatnya kementerian kesehatan dan anak, bersama National AIDS Council Zimbabwe dan Joint United Nations Programme on HIVIAIDS.

Tema yang diangkat dalam program ZNASP ini ialah From Commitment to Action. Maksud dari tema ini guna merefleksikan kepercayaan berbagai pihak pemerintah Zimbabwe dan seluruh stakeholder nasional maupun internasional serta multi sektoral dalam melawan HIV dan AIDS. Sehingga sebuah komitmen bersama dianggap penting untuk menanggulangi permasalahan terkait HIV di Zimbabwe yang membutuhkan perhatian yang besar dan tindakan yang terkoordinasi. Beberapa stakeholder yang memiliki peran penting dalam proses realisasi ZNASP ini antara lain: organisasi non pemerintah, masyarakat umum, Organisasi Berbasis Agama, Organisasi berbasis komunitas seperti People Living with HIV (PLWHA), sektor privat dan institusi-institusi yang memiliki kepedulian lebih untuk berkontribusi dalam HIV dan AIDS serta bekerja dengan komunitas. Selanjutnya juga melibatkan kementerian pemerintah, otoritas local dan National AIDS Council(NAC).

Kebijakan dan kerangka kerja strategis yang dijalankan berdasarkan prinsip "Three One" dan menyediakan kerangka kerja nasional untuk penekanan tingkat penderita HIVIAIDS di Zimbabwe yang dilakukan oleh berbagai pihak, antara lain pemerintah, masyarakat sipil, sektor privat dan rekan-rekan pembangunan. Prinsip "Three one" ialah satu persetujuan kerangka kerja dalam menanggapi HIVIAIDS yang menyediakan dasar koordinasi dalam kerjasama dengan berbagai pihak, kedua adalah satu otoritas koordinasi AIDS nasional dengan ruang lingkup yang luas dan beragam, dan terakhir satu persetujuan dalam sistem evaluasi dan pengawasan pada level negara. Program ZNASP ini tidak bermaksud untuk mengganti atau menyamai sektor-sektor strategi penanggulangan HIV dan 
AIDS Lainnya, begitu pula dengan detail kerja-kerja operasional, rencana penanggulangan ataupun intervensi pendanaan. Namun, ZNASP menyediakan kerangka dan konteks dalam berbagai sektor dan rencana strategis lainnya serta pendanaan-pendanaan yang dapat dirumuskan, diawasi, dan dikoordinasikan.

\section{Tingkat Penderita HIVIAIDS di Zimbabwe}

Prevalensi HIV di Zimbabwe mengalami penurunan yang besar dalam beberapa tahun terakhir, dengan angka yang menurun dari 26\% menjadi 14\% antara tahun 1997 dan 2009. Dalam publikasi jurnal kesehatan PLoS, beberapa peneliti mencari tahu alasan terhadap penurunan ini dan mencoba menemukan penyebab yang bisa dipelajari dan diterapkan di tempat lain. Berdasarkan tulisan Carole Leach-Lemens, yang dilansir dalam situs aidsmap.com dan diterbitkan pada 4 Juni 2010. Terdapat penurunan tingkat penderita HIV di Zimbabwe, dimana la menekankan bahwa perilaku menjadi sektor yang mendukung penurunan tingkat HIV ini. Menurut temuan yang diterbitkan oleh Simon Gregson dan rekan dalam International Journal of Epidemiology, perubahan perilaku dan tingginya angka kematian AIDS berdampak pada penurunan yang bermakna dalam prevalensi HIV di Zimbabwe dari 29\% di tahun 1997 sampai mendekati 16\% di tahun 2007.

Menurut Clemens Benedikt, manager penanggulangan HIV di UNFPA Zimbabwe, perubahan perilaku terkait dengan HIV terjadi karena mulai banyaknya orang-orang yang membicarakan tentang HIV dan hal ini kemudian mempengaruhi perilaku seksual mereka. Selain itu faktor lain yang mendukung penurunan penyebaran HIV adalah menurunnya tingkat perilaku dengan pasangan seksual yang lebih dari satu, hanya 30\% laki-laki melaporkan bahwa mereka masih terlibat dalam hubungan extra-marital, atau terlibat seks dengan lebih dari satu pasangan. Hal ini dapat dianggap sebagai hal yang mendukung penanggulangan program HIV di Zimbabwe. Ditambah lagi dengan dukungan media massa dan komunikasi antar personal melalui gereja, tempat kerja, teman dan keluarga. Program yang mereka kampanyekan ialah akibat dari memiliki beberapa pasangan seks dan mempromosikan penggunaan kondom dalam melakukan hubungan seksual.

Berdasarkan studi yang telah dilakukan, terdapat beberapa perubahan signifikan terkait norma-norma seksual. Sebagai contohnya, dalam beberapa tahun sebelumnya, laki-laki berkumpul di tempat minum bir cenderung dikelilingi oleh para perempuan, beberapa dari mereka adalah pekerja seks. Kemudian terjadi perubahan di tempat-tempat seperti demikian yang lebih banyak dipenuhi oleh laki-laki saja. Selain itu, krisis ekonomi yang parah juga memainkan peran yang penting dan member pengaruh. Banyak laki-laki yang melaporkan bahwa mereka memiliki penghasilan atau uang yang sedikit untuk mempertahankan gaya hidup yang memiliki pasangan lebih dari satu, dan sama halnya untuk menggunakan jasa pekerja seks. Walau bagaimanapun juga, hal ini dinyatakan sebagai faktor pendukung yang mempengaruhi penurunan tingkat HIV, tercatat pada krisis besar-besaran yang terjadi pada 2002 merupakan penurunan tingkat penurunan HIV terbesar di Zimbabwe

Hasil analisis penelitian yang diterbitkan maupun yang tidak diterbitkan dari prevalensi HIV di Zimbabwe dari pertengahan tahun 1980 sampai seterusnya. Perkiraan nasional menunjukkan peningkatan di awal sampai pertengahan tahun 1990, dan angka ini menjadi stabil di akhir tahun 1990 -an pada tingkat $29,3 \%$ sebelum menurun menjadi $15,6 \%$ pada tahun 2007. Penderita HIVIAIDS di Zimbabwe mulai tahun 2007 yakni sebanyak 16, $1 \%$, tahun 2008 sebanyak $15.1 \%$, dan tahun 2009 sebanyak 14, 3\%. Perbedaan Jumlah ratarata sebanyak $1 \%$ setiap tahunnya dalam kurun waktu 3 tahun. Dalam data jumlah yang lebih spesifik yakni pada orang dewasa dan anak- anak jumlah totalnya sebanyak 1.282.635 orang pada tahun 2007, pada 2008 sebanyak 1.226 .781 orang, dan pada 2009 sebanyak 1.187.122. Data ini berdasarkan laporan nasional pemerintah Zimbabwe (Zimbabwe Country Report, 2010).

\section{Program UNAIDS di Zimbabwe}


Dalam penanggulangan HIVIAID di Zimbabwe, UNAIDS memiliki program yang melibatkan banyak pihak. Diantaranya terdapat beberapa program yang melibatkan peran dari stakeholder dan terdapat pula program UNAIDS yang turut bekerja sama dan mendukung program kerja pemerintah Zimbabwe dalam menangani HIVIAIDS.

Gambar 1

\section{Program-program penanggulangan HIVIAIDS}

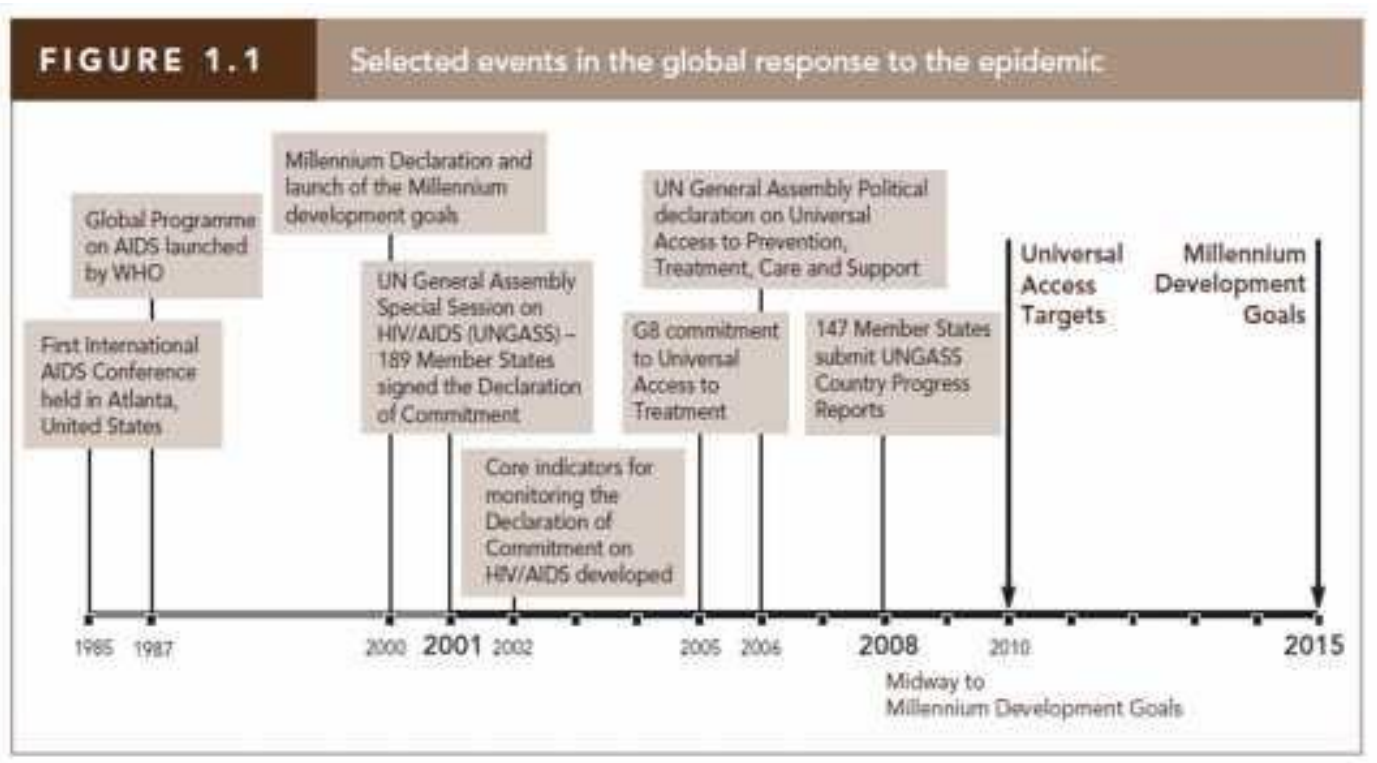

(sumber: UNAIDS Global Report, 2008)

Selain itu terdapat beberapa program yang dilakukan oleh UNAIDS dan lebih spesifik. Berikut beberapa program UNAIDS di Zimbabwe, yaitu:

\section{Task Force on Women, Girls and HIVIAIDS in Southern Africa Program}

Pada kuartal ketiga 2006, UNAIDS Sekretariat, termasuk Sekretariat Koalisi Global tentang Wanita dan AIDS, melakukan tindakidentifikasi dana untuk mereview kemajuan negaranegara yang termasuk dalam program Task Force, yakni pada masalah kesetaraan gender dan tanggapan AIDS nasional. Selain itu juga melakukan identifikasi mitra yang dapat membantu dalam menjalankan program dan menyusun laporan program ini.Pada tahun 2004. UNAIDS / UNICEF, melakukan kerjasama untuk mengembangkan Laporan Satuan Tugas PBB Sekretaris Jenderal pada perempuan, anak perempuan dan HIVIAIDS di Afrika Selatan. Pada bulan Juni 2006, Badan Koordinasi Program UNAIDS bermitra dengan pemerintah nasional dalam melakukan penilaian terhadap gender dan rencana program AIDS nasional sertamenyerahkan pelaksanaan program kepada Badan Koordinasi Program, pada pedoman 2007 pertemuan, teknis dan kebijakan untuk mengatasi isu-isu gender dalam cara yang praktis untuk digunakan oleh pemerintah, program AIDS nasional, donor, lembaga internasional, sistem PBB dan organisasi non-pemerintah dalam menanggapi peningkatan feminisasi epidemi.

Proyek ini didukung oleh dana dari Koalisi Global tentang Wanita dan AIDS, dan mitra yang dipilih yaitu Open Society Initiative in Southern Africa (OSISA). staf yang relevan dari OSISA menjadi bagian kelompok ahli yang bekerja sama mengumpulkan laporan mengenai proyek ini.

Pada bulan Februari 2007, OSISA membahas mengenai perkembangan di masing-masing dari sembilan negara yang berfokus pada dokumen nasional, proses dan laporan penelitian tentang gender dan HIV. Pada bulan Maret dan April 2007, pembahasan ini diikuti oleh 
sembilan negara: Botswana, Lesotho, Malawi, Mozambik, Afrika Selatan dan Swaziland. kunjungan Negara terdiri dari sekitar lima hari, dan dilengkapi dengan telepon dan wawancara informan dengan Pemerintah, pejabat PBB dan anggota masyarakat sipil.

\section{United Nation General Assembly on Special Session}

United Nation General Assembly Special Session (UNGASS) on AIDS adalah sesi khusus dalam Sidang Umum PBB yang membahas tentang AIDS, di mana pada Sidang Umum PBB ke-26 tanggal 25-27 Juni 2001 di New York melahirkan kesepakatan bersama yang dinamakan . "Deklarasi Komitmen Sidang Umum PPB terhadap HIV \& AIDS" (Declaration of Commitment on HIVIAIDS). Berapa komitmen dari deklarasi tersebut antara lain menyangkut masalah: kepemimpinan; pencegahan; perawatan, dukungan dan pengobatan; HIV \& AIDS dan HAM; mengurangi kerentanan; anak-anak yatim piatu korban HIV dan terjangkit AIDS; mengurangi dampak sosial ekonomi; penelitian dan pengembangan; HIV \& AIDS di wilayah konflik dan bencana alam; sumber daya; serta tindak lanjut.

Sebagai tindak lanjut dari komitmen tersebut, setiap negara yang menandatangani wajib membuat laporan tertulis setiap 2 tahun sekali. Di mana salah satu indikator penting dari UNGASS tentang AIDS ini adalah pengisian National Composite Policy Index (NCPI) yang berupa kuisioner yang harus diisi serta diserahkan sebagai bagian dari laporan kemajuan negara terhadap komitmen yang dicetuskan pada tahun 2001 tersebut. NCPI sendiri terdiri dari 2 bagian, yaitu bagian A yang ditujukan untuk pemerintah (mencakup rencana strategis, dukungan politik, pencegahan, pengobatan, perawatan dan dukungan, serta uang) dan bagian $B$ yang ditujukan untuk perwakilan dari organisasi masyarakat sipil, lembaga bilateral dan PBB (mencakup HAM, keterlibatan masyarakat sipil, pencegahan, perawatan dan dukungan).

\section{Kampanye Sunat Laki-Laki di Afrika}

Praktek sunat diperkirakan telah dibawa ke suku berbahasa Bantu di Afrika baik oleh orangorang Yahudi setelah salah satu dari banyak pengusiran mereka dari negara-negara Eropa, atau dengan Moor Muslim yang melarikan diri setelah penaklukan Spanyol pada tahun 1492. Di paruh kedua milenium pertama, penduduk dari timur laut Afrika berpindah ke selatan dan bertemu dengan suku Arabia, Timur Tengah dan Afrika Barat. Orang-orang ini pindah ke selatan dan membentuk apa yang dikenal hari ini sebagai Bantu. Suku Bantu diamati menegakkan apa yang disebut sebagai hukum Yahudi, termasuk sunat, di abad ke 16. Sunat dan unsur-unsur pantangan Yahudi masih ditemukan di antara suku- suku Bantu (Milos, 1992).

Untuk negara-negara di Afrika, Beberapa suku di Afrika, seperti Yoruba dan Igbo di Nigeria, biasa menyunatkan bayi mereka. Prosedur ini juga dilakukan oleh beberapa suku atau garis keluarga di Sudan, Zaire, Uganda dan selatan Afrika. Beberapa dari suku-suku ini, sunat tampaknya budaya yang, dilakukan tanpa signifikansi agama tertentu atau niat untuk membedakan anggota suku. Bagi orang lain, sunat bisa dilakukan untuk pemurnian, atau ditafsirkan sebagai tanda penaklukan. Di antara suku-suku ini bahkan sunat yang dilakukan karena alasan tradisi, sering dilakukan di rumah sakit.

Populasi penduduk Zimbabwe sebanyak $87 \%$ Kristen $^{45}$, dan tidak menerapkan sunat dalam agama. Salah satu bab dari Perjanjian Baru, Kisah Para Rasul 15 mencatat bahwa Kristen tidak mewajibkan sunat. Kristen juga tidak melarangnya; Injil Lukas menyebutkan bahwa Yesus sendiri disunat. Pada tahun 1442, pimpinan Gereja Katolik menyatakan bahwa sunat tidak diperlukan. Kristen Koptik mempraktekkan sunat sebagai suatu ritus. Gereja Ortodoks Ethiopia mengajak untuk sunat, dengan prevalensi hampir universal di antara laki-laki Ortodoks di Ethiopia. Di Afrika Selatan, beberapa gereja Kristen tidak menyetujui sunat, sementara yang lainnya mewajibkan sunat bagi anggotanya.

Dalam tulisan oleh Laura Lopez Gonzalez dan Roger Pebody pada website www.spirita.or.id pada 17 Juli 2013 menjelaskan tentang kampanye untuk menyunat puluhan ribu pria di Afrika Selatan memiliki hambatan dalam penerimaan pada enam tahun setelah prosedur pertama 
kali direkomendasikan untuk membantu mencegah infeksi HIV. Hal ini dilaporkan oleh para pembicara pada International Conference for the Social Sciences and Humanities in HIV ke2 di Paris.

Organisasi Kesehatan Dunia (WHO) dan UNAIDS mulai merekomendasikan sunat laki-laki sebagai alat pencegahan HIV pada tahun 2007, setelah tiga uji klinis acak skala besar. Studi yang dilakukan di Kenya, Afrika Selatan dan Uganda ini menemukan bahwa sunat laki-laki mengurangi risiko seorang laki-laki untuk terinfeksi HIV sekitar $60 \%$.Setelah rekomendasi internasional, negara dengan prevalensi HIV yang tinggi di Afrika timur dan selatan mengumumkan rencana untuk kampanye sunat laki-laki skala besar. Sekarang para peneliti mengatakan bahwa kampanye di Swaziland, Botswana dan Malawi gagal karena kekhawatiran dari pada laki-laki, komunitas dan negara mengenai apakah sunat laki-laki sesuai untuk mereka.

Para ilmuwan sosial di pertemuan Paris menyatakan bahwa mereka yang melaksanakan sunat laki-laki kurang memberikan perhatian pada makna sosial dari sunat dalam pengaturan yang berbeda (sering kali perbedaan etnis atau agama, atau terkait dengan bentuk maskulinitas tertentu). Walaupun ada bukti bahwa intervensi sunat memiliki efikasi (dalam kondisi yang ideal), intervensi ini hanya akan menjadi efektif (dalam pengaturan dunia nyata) dalam beberapa situasi, ketika ada faktor kontekstual termasuk jaringan sosial, debat politik dan nilai budaya yang menguntungkan. Para peneliti biomedis telah memisahkan pemahaman apa pun dari efikasi alat ini dari bagaimana mereka berjalan dalam dunia yang sesungguhnya.

Di Swiss, sekitar seperempat dari semua orang antara usia 15 dan 49 tahun diperkirakan akan hidup dengan HIV. Dengan tingkat prevalensi HIV tertinggi di dunia, Swaziland adalah pengadopsi awal dari rekomendasi WHO. Pada tahun 2009, negara tersebut berencana untuk menyunat 150,000 laki-laki dalam waktu dua tahun. Tapi pada tahun 2011, negara ini hanya memenuhi sekitar $12 \%$ dari target ini, menurut Alfred Khehla Adams dari Universiteit van Amsterdam.

Untuk mengetahui mengapa sunat tidak begitu populer di kalangan pria Swaziland, Adams mewawancarai pria di distrik Kwaluseni dari Manzini, Swaziland melalui kombinasi diskusi kelompok terfokus dan wawancara. la menemukan bahwa karena laki-laki takut mengalami pengurangan kenikmatan seksual dan efek samping yang mungkin terjadi, pria Swaziland merasa prosedur ini mengancam mereka sebagai pria dewasa.

Meskipun demikian, tiga uji klinis acak besar menemukan bahwa hanya sebagian kecil, antara 1,5 dan $3,8 \%$ sunat mengakibatkan komplikasi seperti luka atau bengkak. Para pria juga melaporkan bahwa mereka tidak melihat nilai dari sunat laki-laki medis jika penggunaan kondom masih disarankan untuk mengikuti prosedur.

Penelitian dari Botswana juga menunjukkan masalah kesulitan untuk penerimaan sunat. Pada tahun 2009 Botswana berkomitmen untuk menyunat 100,000 orang setiap tahun. Pada tahun 2012, negara itu mampu menyunat sekitar 40,000 orang, lebih sedikit dari target yang ditekankan oleh WHO, menurut Masego Thamuku dari University of Bergen.

Melakukan penelitian di Mochudi, Botswana, Thamuku menemukan bahwa kampanye sunat nasional yang pada awalnya diterima dengan baik oleh para pemimpin dan masyarakat tradisional telah kurang diminati. Hal ini sebagian besar disebabkan oleh cara kampanye dipublikasikan dan dilaksanakan di antara masyarakat Tswana yang sudah mempraktekkan sunat tradisional melalui sekolah inisiasi tradisional.

Namun walaupun sebagian besar pembicara menyarankan bahwa ahli kesehatan masyarakat dan organisasi internasional sangat antusias mengenai sunat laki-laki medis, analisis yang sangat berbeda datang dari Ann Swidler dari University of California. Meneliti dokumen kunci dari WHO dan UNAIDS pada tahun 2007, ia menemukan bahwa para penulis enggan menerima bukti ilmiah yang luar biasa, dengan dokumen yang penuh peringatan. Dokumen tersebut menegaskan bahwa sunat harus diberikan bersama paket komprehensif dari intervensi pencegahan HIV. Swidler berpendapat bahwa ini mengaburkan fakta bahwa sunat laki-laki memiliki khasiat yang terbukti sedangkan intervensi yang ada seperti 
konseling dan tes sukarela atau program untuk mempromosikan dan mendistribusikan kondom tidak memiliki kemanjuran yang terbukti. Salah satu alasan keengganan mengenai sunat adalah bahwa hal itu menyentuh kepekaan dan kecemasan terhadap budaya, termasuk mengenai hubungan non kolonial Eropa dan Amerika Utara disatu sisi, dan Afrika di sisi lain

\section{Program-Program Pendidikan HIVIAIDS}

Dalam menangani kasus ini, UNAIDS membuat beberapa program dimana program ini dilakukan dalam bentuk edukasi, pencegahan, perawatan, pengobatan dan dukungan yang komprehensif. Pendidikan (Education) yang dilakukan dalam upaya menangani kasus HIVIAIDS adalah dengan mengajarkan tentang HIVIAIDS disekolah-sekolah. Pada tahun 2006 Departemen Pendidikan, Olahraga, Kebudayaan dan UNICEF (salah satu cosponsor UNAIDS) memulai pola pelatihan guru primer dan sekunder disekolah. Pada akhir tahun 2007 sekitar 2.753 Sekolah Dasar dan Menengah telah mendapatkan pelatihan itu. Di luar sekolah, upaya untuk mendidik atau menginformasikan kepada masyarakat tentang HIV dan AIDS bisa berupa selebaran, televisi dan radio, dan drama. Edukasi yang diberikan berupa pendidikan mengenai bahaya HIVIAIDS, cara pencegahannya dan cara pengobatannya, sehingga anak-anak telah memiliki pengetahuan tentang HIV dari usia dini dan anak-anak juga mampu membatasi diri dari virus HIV tersebut.

Selain bantuan berupa membuat program dan edukasi, UNAIDS juga memberikan bantuan dana. UNAIDS memberikan bantuan kepada semua penderita HIV-positif di Zimbabwe sebesar US\$ 4 per orang di tahun 2004. UNAIDS bekerjasama dengan Global Fund. Program yang juga diterapkan di Zimbabwe adalah ABC yaitu Abstain, Befaithful, use Condom campaign. Maksud Abstain adalah jangan melakukan hubungan seksual diluar nikah (Dilarang seks bebas), Be faithful adalah bersikap setia terhadap pasangan (suami/istri), use Condom campaign adalah cegah dengan menggunakan kondom.

Struktur lainnya dalam UNAIDS yakni Program coordinating board (PCB).UNAIDS dibimbing oleh PCB, sebagai badan pemerintahan UNAIDS. Badan ini beranggotakan perwakilan dari 22 negara diseluruh dunia, perwakilan dari 10 kosponsor dan 5 perwakilan NGO, dimana di dalamnya terdapat asosiasi pengidap HIVIAIDS. Bukan hanya itu keberadaan dari UNAIDS ini juga berusaha melakukan fungsi-fungsi lainnya melalui kerjasama dengan berbagai pihak. Diantaranya adalah proyek Task Force on Women, Girls and HIVIAIDS in Southern Africa Program. Proyek ini didukung oleh dana dari Koalisi Global tentang Wanita dan AIDS, dan mitra yang dipilih yaitu Open Society Initiative in Southern Africa (OSISA). staf yang relevan dari OSISA menjadi bagian kelompok ahli yang bekerja sama mengumpulkan laporan mengenai proyek ini.

Proyek ini merupakan bentuk implementasi dari peran-peran UNAIDS dalam Policy Development and Research, Bertujuan untuk mengidentifikasikan, membangun dan menjadi sumber utama di dalam penelitian pada skala internasional. Technical Support, menyelidiki penyebab dan menyediakan bantuan teknis untuk memperkuat kapabilitas nasional dalam memperkuat respon terhadap HIVIAIDS. Advocacy, sebagai pelopor yang memulai respon yang komprehensif dari berbagai sector dan didukung dengan bantuan teknis dan strategis yang baik serta akan disediakan sumber yang memadai. Terakhir Coordination, bertujuan mengkoordinasikan dan merasionalisasikan kegunaan-kegunaan dari para sponsor dan badan PBB lain dalam mendukung usaha mengurangi epidemik.

Keterlibatan UNAIDS dalam upaya penanggulangan HIVIAIDS di Zimbabwe kemudian membentuk sebuah hubungan kerjasama antar kedua belah pihak. Sebagai sebuah organisasi internasional UNAIDS memiliki bentuk-bentuk interaksi dengan Zimbabwe yang merupakan sebuah negara dengan sistem pemerintahannya sendiri. Interaksi yang tercipta dalam berjalannya kerjasama antara kedua pihak berjalan secara hierarki secara sistem. UNAIDS masuk sebagai salah satu bagian dalam program yang telah disusun oleh pemerintah Zimbabwe sebagai pihak organisasi yang bekerjasama, yakni dalam program 
ZNASPNamun, berdasarkan interaksi kerjasama dalam melakukan program-program Zimbabwe dan UNAIDS memiliki kerjasama yang dinamis. UNAIDS menyesuaikan programprogram yang dilakukannya dengan kondisi Zimbabwe serta turut bekerja sama dan terlibat dengan pihak-pihak lain yang juga menunjang penanggulangan HIVIAIDS di Zimbabwe.

Keberadaan UNAIDS di Zimbabwe telah menurunkan tingkat penderita HIVIAIDS di Zimbabwe. Penurunan ini dapat dilihat dari berkurangnya angka- angka statistik yang dikeluarkan oleh pemerintah Zimbabwe setiap tahunnya. Selain oleh pemerintah, data yang dikeluarkan oleh WHO juga menunjukan penurunan angka tingkat penderita HIVIAIDS di kawasan sub Saharan Afrika. Penurunan angka penderita ini berdasarkan hasil penelitian yang dilakukan oleh pihak Zimbabwe dan dikeluarkan sebagai laporan nasional setiap beberapa tahun.

Tabel 1.

Penurunan tingkat penderita HIVIAIDS di Zimbabwe selama bekerjasama dengan UNAIDS

\begin{tabular}{lccc} 
Penderita HIVIAIDS & \multicolumn{3}{c}{ Selama UNAIDS terlibat } \\
\cline { 2 - 4 } & 2007 & 2008 & 2009 \\
\hline Tahun + & $16,1 \%$ & $15,1 \%$ & $14,3 \%$ \\
\hline Laki-laki 15-24 tahun & $3,3 \%$ & $3,3 \%$ & $3,2 \%$ \\
\hline Perempuan 15-24 tahun & $7,6 \%$ & $7,2 \%$ & $6,9 \%$ \\
\hline Anak-anak 0-14 tahun & $3,3 \%$ & $3,2 \%$ & $3,1 \%$ \\
\hline
\end{tabular}

Keberadaan UNAIDS di Zimbabwe secara spesifik dapat dilihat dari berbagai programprogram dan kerjasama yang dilakukannya dengan organisasi pemerintah maupun organisasi non pemerintah. Berbagai program dibuat secara berkala dan dengan tujuan spesifik melalui pendekatan yang berbeda pula. Namun, seluruh program-program yang dilakukan walaupun bentuknya beragam, tetap merupakan bentuk dari suatu hal, yakni bantuan internasional.

Lebih jauh lagi mengenai bagaimana bantuan internasional yang diberikan UNAIDS memberi dampak kepada Zimbabwe, ialah sebagai berikut: bantuan luar negeri memiliki berbagai macam dan bentuk yang intinya transfer sumber daya dari satu pemerintah ke pemerintah lain yang berupa barang atau dana. Keberadaan UNAIDS adalah salah satu bentuk bantuan luar negeri dari pemerintah negara lain secara tidak langsung kepada negara-negara yang membutuhkan bantuan untuk menghadapi HIVIAIDS, salah satunya adalah Zimbabwe.

\section{Hambatan Penanggulangan HIVIAIDS di Zimbabwe}

Berdasarkan Laporan nasional penanggulangan HIVIAIDS di Zimbabwe pada tahun 2007 terdapat beberapa hambatan yakni masalah perekonomian Zimbabwe dan Sumber daya manusia. Perekonomian Zimbabwe, ketika beberapa negara di sub sahara Afrika mengalami kenaikan tingkat perekonomian, Zimbabwe merupakan satu-satunya negara yang mengalami penurunan tingkat perekonomian. Pada tahun 2000 sampai 2006 tingkat perekonomian Zimbabwe turun dari $-2 \%$ pada menjadi $-4,6 \%$ (Zimbabwe Economic Development Document, 2007) sebagai akibat dari meningkatnya lingkungan makro ekonomi yang tidak terhentikan. Ketika alokasi dana nasional meningkat, sektor kesehatan yang membutuhkan dana yang lebih akibat HIVIAIDS. Zimbabwe hanya menerima sumbangan dari Perserikatan Bangsa-Bangsa sehingga rendahnya dana sumbangan tidak dapat menutupi upaya penanggulangan masalah HIVIAIDS. Inflasi yang meningkat, pertumbuhan ekonomi yang rendah, tingginya harga minyak dalam pasar internasional dan tingginya beban HIVIAIDS telah mempengaruhi Zimbabwe dalam memberikan penanggulangan yang efektif terhadap HIVIAIDS. selanjutnya Sumber daya manusia, hampir dalam semua bidang Zimbabwe memiliki masalah sumber daya manusia yang tidak menunjang dan semakin tergerus. Terutama pada bidang pendidikan dan kesehatan yang mempengaruhi kualitas 
penanggulangan HIVIAIDS di Zimbabwe. Walaupun Health Service Board (Badan Layanan Kesehatan) telah dibuat namun tidak mampu menutupi gap antara lowongan dan posisi yang disediakan.

\section{KESIMPULAN}

Keterlibatan UNAIDS dalam upaya penurunan tingkat penderita HIVIAIDS di Zimbabwe yakni melalui partisipasi secara khusus yang dilakukan bersama pemerintah Zimbabwe. Melalui satu acuan khusus yang disepakati bersama sebagai bentuk-bentuk atau pola kerja dalam menanggulangi penyebaran HIVAIDS secara global yang dikenal dengan "Three Ones". Persetujuan in merupakan bagian dari program yang melibatkan UNAIDS dan pihak Zimbabwe sendiri, yaitu Zimbabwe National HIV and AIDS Strategic Programme (ZNASP). Persetujuan ini yang kemudian menjadi acuan bersama UNAIDS dan Zimbabwe dalam upaya memerangi virus HIV.

Dampak Keberadaan UNAIDS di Zimbabwe telah menurunkan tingkat penderita HIVIAIDS di Zimbabwe. Penurunan ini dapat dilihat dari berkurangnya angka-angka statistic yang dikeluarkan oleh pemerintah Zimbabwe setiap tahunnya. Proses penurunan tingkat penderita HIVIAIDS di negara ini dengan melakukan beberapa program-program kerjasama yang lebih spesifik dan dukungan dari bantuan luar negeri.

Hambatan UNAIDS dalam upaya menurunkan tingkat penderita HIVIAIDS di Zimbabwe antara lain yakni kondisi-kondisi yang tidak terlepas dari pengaruh-pengaruh di Zimbabwe seperti kebudayaan masyarakat, tingkat perekonomian yang rendah, dan sumber daya manusia yang kurang.

\section{DAFTAR PUSTAKA}

African Migrations: From Tension to Migration. United nations Department of Information Vol. 19 No.14 Januari 2016. http://wwww.un.org/en/africarenewal/vol19no14eng.pdf. Diakses pada 10 Januari 2016.

Aids Stakeholders. http://www.aids.md/coordination/aids-stakeholders /un/tor-un- tg/theme group.diakses pada tanggal 04 Januari 2016

Anderson, Mark. 2014. Donation to Africa, donation from west mask '\$60 looting' of continent. The Guardian.15 Juli 2014.http://www.theguardian.com/globaldevelopment/2014/jul/15/aid- africa-west-looting-continent. Di pada 03 Januari 2016.

Anonim.2006. Modul Pelatihan untuk Pencegahab HIVIAIDS, YASIN dan UNICEF: Makassar

Archer, Clive. 1983. Organization International. Allen \& Unwin Ltd, London.

Bennet, Le Roy. 1997. International organization: principles and issues. Prentice hall inc, New jersey.

Birrell, lan. 2015. No, Mister, our billion in foreign aid actually make migrants more likel to come here. Daily Mail UK.11 Agustus

2015.http://www.dailymail.co.uk/debate/article-3193055/No-Minister- billions-foreignaid-actually-make-migrants-likely-come-here.html. Diakses pada 03 Januari 2016.

Brookes, Peter and Shin, Jie Hye. 2006. China's Influence in Africa: Implications for the United States. Heritage. 22 February 2006. http://www.heritage.org/research/reports/2006/02/chinas-influence-in-africaimplications-for-the-united-states. Diakses pada 03 januari 2016.

Burchill, Scott, dkk. 1996. Theories of International Relations Third Edition. 90 Tottenham Court Road, London.

Plano, Jack, Roy Olton. 1999. Kamus Hubungan Internasional. Terjemahkan oleh Wawan Juanda.

Case, Kelsey dkk. Development and Future Directions for the Joint United nations Programme on HIVIAIDS estimates. Official Journal of The International Aids Society. Volume 28 November 2014.

Catherine Marshall dan Gretchen B Rossman.1994 Designing Qualitative Research $2^{\text {nd }}$ Edition.California: Sage Publication. 
Checo, Tafadzwa dan Bhatasar, Sandra. 2012. HIV and AIDS Programme in Zimbabwe: Implication for Health System. ISRN Immunology. Volume 2012, Article ID 609128, 11 pages.http://dx.doi.org/10.5402/2012/609128. Diakses pada 10 Januari 2016.

Doyle, Mark. 2013. African's Remittances Outweigth Western Aid. BBC.17 April 2013.http://www.bbc.com/news/world-africa-22169474. Diakses pada 03 Januari 2016.

Easterly, William. 2010. Foreign Aid for Scoundrells. The New York Review of Books. 25 November 2010.http://www.nybooks.com/articles/2010/11/25/foreign-aidscoundrels/. Diakses pada 03 Januari 2016.

Elias, Juanita dan Sutch, Peter. 2007. International Relations The Basics. Routledge, New York.

Ghosh,Peu.2009. International Relations, New Delhi, PHI

Griffiths, Martin. 2007. International Relations Theory for the Twenty-First Century. Routledge, New York.

Gudono. 2012. Teori Organisasi. Alfabeta, Jogjakarta.

HIV and AIDS in Zimbabwe, http://www.avert.org/aids-zimbabwe.htm, diakses pada tanggal 15 September 2015 http://data.unaids.org/publications/IRC-Pub03/una96-3en.Pdf, diakses pada tanggal 02 Januari 2016

http://www.unaids.org/en/ Cosponsors/CCO/default.asp, diakses pada tanggal 03 Januari 2016

Jackson, K. 1990. Quasi-States: Sovereignty. International Relation and the Third World. Cambridge: Cambridge University.

Jackson, Robert H. dan Georg Sorensen. 1999. Pengantar Studi Hubungan Internasional. Yogyakarta: Pustaka Pelajar.

John Hutton. 2001. Global Health, JointU.N Programme on HIVIAIDS Needs to Strengthen Country-Level Effort and Measure Result. UnitedStates.

Kartasasmita, Koesnadi. 1977. Organisasi dan Administrasi Internasional. JLembaga Penerbitan Sekolah Tinggi IImu Administrasi: Bandung Krisna. Didi. 1993 Kamus Politik Internasional. Grasindo: Jakarta.

Kusumohamijojo, Budiono. Hubungan Internasional, kerangka untuk analisis. Bina Cipta Karya: Jakarta

Lamy,Steven. 2008. Contemporary Approaches:Neo-realism and neo-liberalism in "The Globalisation of World Politics, Baylis, Smith and Owens. Oxford University Press, USA.

Lancaster, Carol. 2007.Foreign aid. Diplomacy, Development, Domestic Politics, University of Chicago Press, Chicago.

M Saeri.Teori Hubungan Internasional Sebuah Pendekatan Paradigmatik. Jurnal Internasional, vol. 3.No. 2. Februari 2012

Milos, Marilyn F; Macris, Donna (1992)."Circumcision: A Medical or a Human Rights Issue?". Journal of Nurse-Midwifery

Mochtar Mas'oed. 1990. IImu Hubungan Internasional: Disiplin dan Metodologi. Edisi Revisi. Jakarta: LP3ES

Perwita, Anak Agung Banyu dan Yanyan, Mochamad Yani, 2005, Pengantar IImu Hubungan Internasional, Rosda : Bandung

Reus-Smit, Christian. 2005. Theories of International Relations, ed. Scott Burchill, London.

Richmond, Oliver. 2011. A Post-Liberal Peace. Abingdon, Oxon: Routledge, London.

Shah, Anub. 2000. AIDS in Africa. Global Issues. 29 November 2009. http://www.globalissues.org/article/90/aids-in-africa. Di akses pada 03 Januari 2016.

Soerjono Soekanto. 2001. Sosiologi Suatu Pengantar, Edisi Keempat. Jakarta: PT.Raja Grafindo Persada

T. May Rudy. 1998. Administrasi dan Organisasi Internasional. Bandung: Refika Aditama.

Ti dan Kerr. The Impact of Harm Reduction on HIV and illicit Drug Use. Harm Reduction Journal 2014 vol.11 no.7.

UNAIDS, 2012. Global report: UNAIDS report on the global AIDS epidemic 2012, UNAIDS: 
Jenewa

UNAIDS. "About UNAIDS". http://www.unaids.org/en/aboutunaids/, diakses pada tanggal 18 September 2015

UNAIDS. "Fact About UNAIDS". http://data.unaids.org/Publications/IRCPub03/una96-3en.Pdf. diakses pada tanggal 03 januari 2016

UNAIDS. 2006. AIDS Epidemic Update: Special Report on HIVIAIDS. WHO library and Cataloguing-in-Publication Data: Zwitzerland

UNAIDS. 2006. EPI Report 2006.

http://data.unaids.org/pub/Epi/Report2006/2006 EpiUpdate en.pdf. Diakses pada 20 September 2015

UNAIDS. 2007. AIDS Epidemic Update: Special Report on HIVIAIDS. WHO library and Cataloguing-in-Publication Data: Zwitzerland

UNAIDS. 2008. AIDS Epidemic Update: Special Report on HIVIAIDS. WHO library and Cataloguing-in-Publication Data: Zwitzerland

UNAIDS. 2009. AIDS Epidemic Update: Special Report on HIVIAIDS. WHO library and Cataloguing-in-Publication Data: Zwitzerland

UNAIDS. 2010. AIDS Epidemic Update: Special Report on HIVIAIDS. WHO library and Cataloguing-in-Publication Data: Zwitzerland

UNAIDS. 2011. The UNAIDS Vission: Zero New HIV Infection. Zero Discrimination. Zero AIDS-Related death. UNAIDS JC2216E.JC2216_WorldAIDSday_report_2011_en_pdf. Diakses pada 3 Januari 2016.

UNAIDS. 2015. The Gap Report. UNAIDS_Gap_report_en_pdf.Diakses pada 10 Januari 2016.

USAID, http://www.library.upnvj.ac.id/pdf/s1hi09/204613005/bab1.pdf, diakses pada tanggal 20 September 2015

Walter Carlsnaes, Thomas Risse dan Beth A simmons. 2013. Hand Book of International Relations (Hand Book Hubungan Internasional). Nusa Media: Bandung

Weiss, T. G. and C. Collins. 1996. Humanitarian Challenges and Intervention. Boulder: Westview Press.

Zartman, W. I. 1995. Collapsed States: The Disintegration and Restoration of Legitimate Authority. Boulder: Lynne Rienner.

Zimbabwe Country Report. 2006. United nations General Assembly (UNGASS) Report. Zimbabwe

Zimbabwe Government. 2008 United Nations General Assembly Report On HIV- AIDS. Zimbabwe Country Report : Zimbabwe

Zimbabwe. 2008. United Nations General Assembly Report On HIVIAIDS, Zimbabwe Country Report., Zimbabwe 